\title{
Efforts to Develop Fine Motor Aspects in Coordinating Eyes and Hands to Make Complex Movement Using Explicit Instruction Model and Assignment Method
}

Mahlan Asmar*, Wahyu

Department of Early Childhood Education, Universitas Lambung Mangkurat, Banjarmasin, Indonesia.

\begin{tabular}{|c|c|}
\hline ARTICLE INFO & A B STRACT \\
\hline \multirow[t]{2}{*}{$\begin{array}{l}\text { Received: 09-03-20I7 } \\
\text { Revised: 08-05-20I7 } \\
\text { Accepted: 07-06-20I7 } \\
\text { Keywords: } \\
\text { Fine Motor, Coordinate } \\
\text { Eyes and hands, Explicit } \\
\text { Instruction, Assignment } \\
\text { Method }\end{array}$} & $\begin{array}{l}\text { This research is aimed to discover the teacher activities, the children activities, and } \\
\text { the results of fine motor aspect development in coordinating the eyes and the hands } \\
\text { using combination of explicit instruction model and assignment method. This } \\
\text { research was classroom action research qualitative approach and conducted on a } \\
\text { group of children at Budi Mulia Kindergarten of Kandangan of South Hulu Sungai } \\
\text { District within } 2 \text { cycles, the cycle I consisted of } 2 \text { meetings and Cycle II consisted of } \\
2 \text { meetings. Each meeting consisted of } 4 \text { stages planning, implementation, } \\
\text { observation, and reflection. The research results showed that teacher and children } \\
\text { activities increased, and the development of children fine motor aspect were } \\
\text { successfully developing whether individually or classically. }\end{array}$ \\
\hline & $\begin{array}{l}\text { (c) } 2018 \text { The Authors. Journal of K6, Education, and Management (j-K6EM). ISSN: } 2580-2135 \text {. } \\
\text { Published by Graduated Program of Educational Management, Universitas Lambung } \\
\text { Mangkurat, Banjarmasin, Indonesia. This is an open access article under the open journal } \\
\text { systems. }\end{array}$ \\
\hline
\end{tabular}

*Author correspondence: Mahlan Asmar; E-mail: mahlanasmar@gmail.com 


\section{Introduction}

The National Education System Constitution of 2003 on article I, paragraph (I4) states that early childhood education is a developing effort aimed at children from the birth up to six years old that is performed through the providing of educational stimuli to assist the growth and physical as well as spiritual development. So that children have readiness in entering further education (Masitoh, 2009).

The Kindergarten curriculum of A group on fine motor development aspect at the level of expected achievement for early childhood development in the age range of four to five years old, i.e. the child is expected to be able to coordinate the eyes and hand to perform complex movements within a learning. So that the level of development achieved at a stage is expected to develop well (Kemendiknas, 2010).

Based on Kindergarten curriculum of A group on on aspect of fine motor development, at the level of expected development achievement on early childhood in the age range of 4-5 years old in the fine motor aspect, the child is able to create vertical, horizontal, left or right curved, left or right oblique lines, and circle, plagiarize the shape, coordinate the eyes and hand to perform complex movements, perform manipulative movements to produce something by using various media, self-expressions with art work using various media (Kemendiknas, 2010).

In fact, in A group at Budi Mulia Kindergarten of Kandangan of South Hulu Sungai District, some children still have not been able to develop fine motor aspect in coordinating eyes and hand to perform complex movement. From observation data of September and October 2015 semester I, this observation was not only observing children directly on attitudes and behaviors in the learning process but also held interviews to classroom teachers to assess how the child's understanding in the ability of fine motor aspects in coordinating the eyes and hand to perform complex movements. In the indicator of simple folding paper (I-6 folds) neatly. From 24 children, only 8 children $(33.3 \%)$ obtained $\star \star \star$, and IO children (4I.6\%) obtained $\star \star$ and $6(25 \%)$ children obtained $\star$. In the sewing indicator of 10 holes neatly, from 24 children, only IO children (41.6\%) obtained $\star \star \star$, and 9 children $(37.5 \%)$ obtained $\star \star$ and $5(20.8 \%)$ children obtained $\star$. In the indicator of arranging beads, from 24 children, only 6 children $(25 \%)$ obtained $\star \star \star$, and I0 children (4I.6\%) obtained $\star \star$ and 8 (33.3\%) children obtained $\star$. In assessing the learner development,

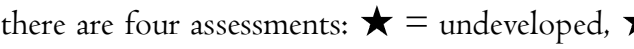

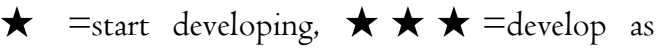
expectation, and $\downarrow \star \star \star \star \star=$ develop very well. children are successful in a learning if they achieve $\star \star \star / \star \star \star \star \star$. While, the assessment of children motor skill in coordinating eyes and hand to perform complex movement is successful if obtaining value (develop as expectation) and obtaining value (develop very well).

The reason is after conversation and communication, A group teacher said that they lack of motivation, the method use is not optimizing the children fine motor development. Most of the activities designed by the teacher have function to develop the cognitive, language, science, and rough motor. Based on the observation result from simple folding paper (I-6 fold), sewing IO hole, and arranging beads, the reason of children have not managed to coordinate the eyes and hand to perform complex movements is the lack of activities that can stimulate fine motor of the children, the monotonous learning process, method and media used are not vary that makes the children get bored. Consequently, the complex movements' performance is still not as expectation.

It means that children have not success in physical development of fine motor in coordinating the eyes and hand to perform complex movements because in learning process, children are less active in coordinating the eyes and hand to perform complex movements. Some of children are difficult to move their hand and focus their eyes, so that they are difficult in coordinating the eyes and hand to perform good complex movements to be a more meaningful form.

Efforts to overcome the difficulties of children in coordinating the eyes and hands to perform complex movements, then learning is implemented through combination of explicit instruction model and assignment method using paper and bead media. Explicit instruction model is a direct 
learning model designed to develop children learning on skills knowledge that can be taught through pattern of step-by-step. For this model, the children are trained to be active in skill learning provided individually. Whereas, assignment method is providing knowledge to children with the steps that have been designed first to make the children able to understand and implement the task well. So, the children are not required to be able to move their hand in the form of skill activities, but they just coordinate the eyes and hand to make movement in the form of explicit instruction (direct learning) and the assignment of the task.

Based on the problems above, this research aimed to discover the children activities, the children activities, and the results of fine motor aspect development in coordinating the eyes and the hands using combination of explicit instruction model and assignment method on a group of children at Budi Mulia Kindergarten of Kandangan of South Hulu Sungai District.

\section{Methodology}

A good methodology should bring the researcher to achieve the objective (Dalle, 20I0; Dalle et al., 2017; Derlina et al., 2018). Based on the problems above, combination of explicit instruction model and assignment method using paper and bead media is appropriate to solve those problems, in which children are directly involved in an activity that can improve the knowledge and the skill, the children become more active, excited and interested as well as motivated to follow the learning activities to develop the physical aspect of children fine motor, and the learning outcomes in coordinating the eyes and hand to perform complex movement will develop as expectation.

The steps in problem solving refers to Nico (20I3) and Moeslihatoen (2004), then it is adjusted to the Kindergarten Education that the problem-solving plan applying explicit instruction model and assignment method using paper and bead media is as follows: (I) Teacher conveys the learning objectives in coordinating eyes and hand to perform complex movements and children pay attention as well as respond what have been conveyed (explicit instruction model and assignment method; (2) Teacher shows what media will be used to the children, namely colorful paper or bead, thread or rope, paper glue (cognition) while the children pay attention to (media); (3) Teacher asks the children about the paper or bead used (memory) to coordinate the eyes and hands in performing complex movements while the children answer the questions that have been provided (media); (4) The teacher explains and demonstrates how to perform the tasks in the skills of coordinating the eyes and hands to perform complex movements using paper or bead media with simple paper folding activities (I-6 folds), sewing $\mathrm{IO}$ holes as well as arranging while the children pay attention to (model explicit instruction and assignment method); (5) Teacher examines the understanding by asking the children some questions about coordinating eyes and hands for complex movements, and then children respond and answer what the teacher expects (explicit instruction model); (6) Teacher distributes materials and provides opportunities for the children to coordinate the eyes and hands to make complex movements using paper and bead media according to the formed folding patterns and patterns determined by teacher (convergent thinking) and the child performs the tasks assigned by demonstrating in coordinating eyes and hands using simple paper folding activities, sewing IOhole bucket, and arranging beads (explicit instruction model and assignment method); (7) Teachers guide the children who do not understand yet how to coordinate the eyes and hands to perform complex movements and children have spirit in following the guidance (explicit instruction model); (8) Teacher asks the children about fold pattern formed, picture pattern, and pattern of color or the form sorted after the children finish the task in coordinating the eyes and hands to perform complex movements and the children provide answer as the expectation (explicit instruction model); (9) Teacher provides conclusion to children on the results of coordinating the eyes and hands to perform complex movements by applying activities of simple paper folding, sewing IO-hole bucket, and arranging bead. And the children respond as well as answer well (assignment method)

This research used qualitative approach. According to Arikunto (2010) Qualitative approach is data about class interest or atmosphere and related to teacher activities in teaching and learning process.

This research was classroom action research (CAR). CAR aims to perform corrective action, improvement, and making a better change as the 
effort of problems solving encountered, especially on teaching and learning activities in classroom. In other word, classroom action research is conducted by teacher in classroom by performing selfreflection to improve learning process in classroom. This effort is conducted by performing certain actions in order to find more appropriate and effective ways for everyday problems in classroom (Arikunto, 20I0). Furthermore, according to Arikunto (20I0), CAR has important role and strategic to improve learning quality if it is implemented properly. The research arises because the awareness of the performers who are not satisfied with their performance results. Based on the self-awareness, the concerned performer attempts to complete his work by experimenting repetitively. The process is observed carefully until obtaining process providing the better results.

This Classroom Action Research was conducted on A Group at Budi Mulia Kindergarten of Kandangan with total of 24 children, in the aspect of fine motor development in coordinating the eyes and hand through combination of explicit instruction model and assignment method.

\section{Results and Discussions}

In cycle I of meeting I, children activity in learning process on class average obtained score of 50.4I with "Quite Active" category and classically obtained score of 21.66\% with "Some of Children > Active" category. Even though have achieved quite active criteria, it is necessary to take remedial measure due to many children who have not able to notice, demonstrated, enthusiastically, answered question, and drawn conclusion in explicit instruction (direct teaching) and assignment. This is because the children are still not used to learn the skill to coordinate the eyes and hands. For the beginning of new learning using a combination of explicit instruction model and assignment method, the children activity has reached the "Quite Active" criteria. Therefore, it needs children activity improvement for the next meeting.

In cycle I of meeting 2 have improvement obtaining score of 64.58 with "Active" category and classically obtained 58\%. Although it has improvement in every aspect observed but the percentage is still below the percentage criteria of children activity successful that have been determined. It means that child activity is still unsuccessful due to have not achieved "Very Active" criteria.

In cycle II of meeting I, children activities have improvement obtaining score of 75 with "Active" category and classically obtained 77.49. Although it has improvement in every aspect observed but the percentage is still below the percentage criteria of children activity successful that have been determined. It means that child activity is still unsuccessful due to have not achieved "Very Active" criteria.

In cycle II of meeting 2, the children activity improvement is more optimal by obtaining score of 91.67 with "Very Active" category and classically obtained score of $92.50 \%$. The percentage is included in the successful percentage criteria of children activities reaching "Very Active" criteria. This is satisfying results for children activities that have improved than the previous meeting.

The children activities improvement is due to the teacher accuracy in selecting and set the combination explicit instruction model assignment method. So, it can attract the children, demonstrate the activities to the children, motivated the children, raising the children enthusiasm and learning activity stimulus, provide them opportunity to think or answer and ask themselves as well as foster the self-confidence when concluding activities undertaken. The above is in line with Masitoh (2012) that one of the characteristics of children is curiosity. Early childhood is more noticing, talking, and questioning various things he had seen and heard. According to Hartati (2005) the curiosity is varying, depending on what interests him. It can assist to develop children motivation in learning to practice the picture demonstrated by teacher and coordinate the eyes and hand to perform the complex movements. Basically, children have ability to build and decorate their own knowledge. It is very important to be directly involved in the learning process. Children's learning experience is more gained by playing experiments with real objects through concrete experience. Children have chance to create and manipulate object or idea (Sujiono, 2009).

The development results of children fine motor in cycle I of meeting I obtaining score $\star$ is 3 children, or $12.5 \%$, children obtaining score 
$\star$ is IO children or $4 \mathrm{I} .67 \%$, children obtaining score $\star \star \star$ is II children or $45.83 \%$, and children obtaining score $\star \star \star \star \star$ is 0 children. So, the results of the percentage of classical are II children who have not managed to develop with percentage of $45.83 \%$ and children who managed to develop with percentage of $54.17 \%$. It indicates that the results of children fine motor development in cycle I of meeting I include the undeveloped because there are many children who have not achieved the individual development indicator, obtaining 3 and $4(\star \star \star$ and $\star \star \star \star)$ and classically $>80 \%$ of children obtained 3 and 4 stars $(\star \star \star$ and $\star \star \star \star \star)$. Therefore, it is necessary to make improvement for the next meeting.

In cycle I of meeting 2, the results of fine motor development obtaining score $\star$ is I child or equal to $4.17 \%$, children obtaining score $\star \star$ is 7 children or equal to $29.16 \%$, children obtaining score $\star \star \star$ is 16 or $66.67 \%$. So, the results of classical percentage are 16 children who have not managed to develop with percentage of $66.67 \%$ and children who managed to develop with percentage of $33.33 \%$. It indicates that children fine motor development have improved, but it is unsuccessful because it has not reached the development indicator of individual obtaining 3

and $4(\star \star \star$ and

$\star \star \star)$ and classically $>80 \%$ of children obtained 3 and 4 stars $(\star \star \star \star$ and $\star \star \star \star \star)$. So, it needs to be improved for the next cycle to obtain maximum results and achieve $>80 \%$.

In cycle II of meeting I, children have improvement by obtaining score of $\star \star$ are 5 or $20.83 \%$, children obtaining score of $\star \star \star$ are I7 children or equal to 70.83 , and children obtaining score $\star \star \star \star$ are 2 children or equal to $8.33 \%$. So, it can be said that the percentage results meet the development individually by obtaining 3 and 4

( $\star \star \star \star$ and $\star \star \star \star \star$ ) and classically $>80 \%$ of children obtained score 3 and $4(\star \star \star$ and

$\star \star \star \star)$. It means that it needs improvement for the next cycle in order to obtain maximum result and reaching $>80 \%$.

In cycle II of meeting 2, many children have improvement, in which no one of children obtaining score $\star$ and $\star \star$, children obtaining score $\star \star \star$ are 9 children or equal to $37.5 \%$, and children obtaining score $\star \star \star \star \star$ are I5 children or equal to $62.5 \%$. So, for the classical percentage, no one child who has not succeeded in developing, I00\% developed successfully. Then, it can be concluded that the development results of children language in cycle ii of meeting 2 is in very good development/achieve successful in fine motor development. learning in kindergarten is not only emphasizing playing-oriented learning but also emphasizing development-oriented learning. David Weikart in Masitoh (2005) stated that a development-oriented lesson means that the approach is self-oriented. It means, Kindergarten teacher should understand the needs and characteristics of children development. Explicit instruction model also has many advantages such as children master knowledge and all students are active or involved in learning. The more interesting and fun learning is suitable for kindergarten age. The development of children fine motor skills in coordinating the eyes and hands to perform complex movements also relates to the children characteristics. Other results that prove that using a combination of explicit instruction models and assignment method can improve children learning outcomes, Dahliyani (2015) "Efforts to develop rough motor abilities by moving the arms for flexibility of muscle strength and coordination in throwing and catching the ball through explicit instruction model in B group at Raudhatul Ulum I Kindergarten of Banjarmasin" showed that in cycle I, the percentage of classical obtained 58\% with started to develop category, and then increased in cycle II by obtaining I00\% with developed very well category. Widayati (20I4), "Efforts to improve rough motor skills by performing coordinated jumping movement through explicit instruction in A group at Hunafaa Kindergarten of Banjarmasin" showed that in cycle I, the percentage of classical obtained 33\% with undeveloped category, then increased in cycle II by obtaining $100 \%$ with very good developed category..

\section{Conclussion and Recomendations}

Based on the results of classroom action research conducted on A group at Budi Mulia Kindergarten of Kandangan in coordinating eyes and hand to perform complex movement using combination of explicit instruction model and assignment method, 
it is found that it can develop children fine motor aspect. Kindergarten teachers are suggested to use the combination of explicit instruction model and assignment method.

\section{Acknowledgment}

Thank you for the Head of Education Board of South Hulu Sungai District, and the Principal as well as Teachers of Budi Mulia Kindergarten Kandangan who supported the implementation of this research.

\section{References}

Arikunto, S. (20I0). Penelitian tindakan kelas. Yogyakarta: Aditiya Media.

Dalle, J. (20I0). Metodologi umum penyelidikan reka bentuk bertokok penilaian dalaman dan luaran: Kajian kes sistem pendaftaran siswa Indonesia. Thesis PhD Universiti Utara Malaysia.

Dalle, J., Hadi, S., Baharuddin., \& Hayati, N. (20I7). The Development of Interactive Multimedia Learning Pyramid and Prism for Junior High School Using Macromedia Authorware. The Turkish Online Journal of Educational Technology, November. 7I4-72I.

Derlina., Dalle, J., Hadi, S., Mutalib, A.A., \& Sumantri, C. (2018). Signaling Principles in Interactive Learning Media through Expert's Walkthrough. Turkish Online Journal of Distance Education (TOJDE). I9(4), I47-I62

Kemendiknas. (20I0). Kurikulum taman kanak-kanak pedoman pengembangan program pembelajaran di taman kanak-kanak. Jakarta.

Kikie. (2013). Manik-manik, mengenal ragam dan jenisnya. Online. http://koleksikikie.com/20I3/I2/m anik-manikmengenal-ragam-dan- jenisnya/.

Masitoh. (2009). Strategi pembelajaran tk. Jakarta: Universitas Terbuka. 